Article

\title{
Policy Instrument Supply and Demand: How the Renewable Electricity Auction Took over the World
}

\author{
Oscar Fitch-Roy ${ }^{1, *}$, David Benson ${ }^{2}$ and Bridget Woodman ${ }^{1}$ \\ ${ }^{1}$ Energy Policy Group, University of Exeter, Penryn, TR10 9FE, UK; E-Mails: o.fitch-roy@exeter.ac.uk (O.F.-R.); \\ b.woodman@exeter.ac.uk (B.W.) \\ 2 Environmental Sustainability Institute, University of Exeter, Penryn, TR10 9FE, UK; E-Mail: d.i.benson@exeter.ac.uk \\ * Corresponding author
}

Submitted: 25 May 2018 | Accepted: 9 November 2018 | Published: 28 March 2019

\begin{abstract}
The selection and design of renewable electricity support instruments is an important part of European Union (EU) energy policy and central to the governance of the Energy Union. In 2014, the European Commission published updated guidelines for state aid that are driving the EU-wide implementation of auctions for allocating revenue support to commercial scale renewable electricity generation. This article argues that the RES auction's rapid ascent towards dominance is explained by a coincidence of an activist interpretation of EU state aid law creating demand for knowledge about the instrument and the emergence of a ready source of supply from a burgeoning community of a RES auction specialists and experts. Knowledge gained through EU-wide implementation of auctions further adds to supply of auctions expertise among the community. The implications of positive feedback between instrument demand and the growing supply of knowledge about an instrument reinforces the importance of critical engagement between policymakers and policy experts.
\end{abstract}

\section{Keywords}

auctions; European Union; governance instruments; instrument constituencies; renewable energy; state aid

\section{Issue}

This article is part of the issue "EU Energy Policy: Towards a Clean Energy Transition?", edited by Kacper Szulecki and Dag Harald Claes (University of Oslo, Norway).

(C) 2019 by the authors; licensee Cogitatio (Lisbon, Portugal). This article is licensed under a Creative Commons Attribution 4.0 International License (CC BY).

\section{Introduction}

Renewable energy expansion remains a public policy goal across the European Union (EU) and global leadership in renewables is a primary goal of the Clean Energy Package of legislation, placing it at the heart of the Energy Union (Szulecki, Fischer, Gullberg, \& Sartor, 2016). Member States have taken various approaches to promoting renewables, resulting in multiple national policy instruments. The diversity of instruments used means that public financial support for renewable electricity generation has occupied academic enquiry for many years (del Río \& Cerdá, 2014; del Río \& Gual, 2004; Woodman \& Mitchell, 2011). While the 1990s and 2000s saw scholars debating the relative merits of instruments such as feed-in tariffs (FIT) and tradable quotas
(Mitchell, Bauknecht, \& Connor, 2006), attention has recently shifted to the 'renewable electricity auction' or renewable electricity support (RES) auction for achieving policy objectives. Global experience of using auctions has been mixed, with some encouraging examples as well as others in which the instrument appears poorly matched to policy goals. Of interest here is how and why such auctions have rapidly assumed a prominent position in the EU in preference to other instruments.

Our guiding question is consequently "how did the auction instrument become central to EU renewable electricity governance, given the implementation challenges'? We draw on established and emerging theories of instrument choice, emphasising the importance of the multi-level nature of instrument demand and the concept of the 'instrument constituency' for promoting sup- 
ply. We then discuss the relative importance and interrelation between these two factors and propose theoretical refinements for future research.

We show that the auctions boom reflects changes in the global and European policymaking context, including the increased political salience of RES support costs and important changes to what Howlett (2009) calls the 'governance mode'. Most importantly, we observe the significance of the EU's state-aid modernisation programme (SAM) in pushing the logic of panEuropean competition within RES policy making. We also chart the emergence of a self-reinforcing community of auction advocates fitting the description of an 'instrument constituency' within an emerging literature (Béland, Howlett, \& Mukherjee, 2017; Simons \& Voß, 2017a, 2017b; Sturdy, 2017; Voß \& Simons, 2014). This community, we argue, plays a pivotal role in the 'innovation journey' traversed by RES auctions.

\subsection{Auctions and Renewable Energy Governance}

The auction, the solicitation and ranking of bids, has structured economic relationships since antiquity (Krishna, 2010). The concept has been applied in a wide range of public policy areas, including the allocation of rights to natural resources, oil reserves and radio frequency spectra (Binmore \& Klemperer, 2002; Klemperer, 2004). The application of auctions as a renewable electricity governance instrument is distinct from the instruments conventionally considered 'support mechanisms' such as FIT or tradable quotas. Renewable electricity auctions tend to be characterised by two primary features. Firstly, access to financial support is allocated to prospective electricity producers at discrete intervals in which limited support is available. This contrasts with other support instruments such as FIT or tradable green certificates (TGC), which are, broadly, open to eligible applicants at all times until the scheme is revised, for example to account for target fulfilment. Secondly, the value of the support, usually representing a price-supplement per unit of production, is determined through ranking of applicants' price bids, with the volume of support, measured in overall cost or generation capacity, filled from lowest price to highest. This differs from both FIT, which offer a known fixed-price, and to TGC, the value of which may fluctuate throughout the tenure of support (del Río, 2017; Fitch-Roy, 2016).

Thus, RES auctions, rather than acting as a support instrument, perform an allocative function that can enhance policymakers' ability to control the volume of new renewable electricity projects, while applying a degree of competitive pressure on bidders to offer their true costs. In other words, the financial support awarded through an auction is structured independently from the allocation. In practice, the most common 'awards' offered to auction winners are a fixed per-unit price for production, a very similar offer to that available through a feed-in tariff (Szulecki, 2017) or a sliding premium system or 'con- tracts for difference' in which payments are calculated with reference to a market index (Fitch-Roy, 2016).

Accumulated analyses of auction performance and subsequent refinement mean that RES auction designers have a wealth of material to guide their decisions. Much of the material observes (and proposes measures to correct) bidding strategies and behaviour that may lead to sub-optimal outcomes, such as the infamous 'winner's curse' in which ex ante bids overestimate the contract value or underestimate bidders' costs, often making the project undeliverable (Klemperer, 2004; Thaler, 1988).

Despite disappointing rates of project completion for RES auctions held in the 1990s, often attributed to inadequate penalties for bidders making offers too low to allow projects to proceed, (Agnolucci, 2007; del Río \& Linares, 2014; Mitchell, 1995), the RES auction has rapidly become the predominant renewable policy instrument for supporting large-scale renewable electricity generation globally. In 2005, six countries used auctions to support renewables, by 2016 it exceeded 70 (International Renewable Energy Agency [IRENA], 2017). In the EU, a 2014 update to European Commission guidelines for interpreting state-aid law means that competitive instruments such as auctions are strongly preferred for all schemes requiring state-aid notification, effectively making auctions the default choice for member states wishing to support large-scale renewable electricity deployment (European Commission, 2014).

Contemporary accounts of the recent boom in auctions present them as a functional substitute for their immediate predecessor instruments, especially the feedin tariff, albeit with performance enhancements (del Río, 2017; Gephart, Klessmann, \& Wigand, 2017; Toke, 2015). Observers tend to assume that the RES auction forms part of a 'natural', obvious progression in the evolution of RES support policy and that policymakers with the correct analysis, will (or at least should) tend towards their use (International Energy Agency [IEA] \& IRENA, 2017).

Prior to the recent boom in use, auctions were generally considered inferior to FIT, both in their effectiveness at generating renewables growth and driving innovation, as well as in their cost effectiveness (Butler \& Neuhoff, 2008). Economic theory invoked in support of RES auctions (del Río \& Linares, 2014) is also ambiguous. Martin Weitzman's seminal (1974) essay suggests that quantity-control instruments (such as auctions) should, under conditions of uncertainty, offer welfare benefits over price instruments (such as feed in tariffs) where supply curves are flat relative to demand. The actual shape of these curves for renewable electricity, however, is highly variable and strongly dependent on local resources and supply-chain conditions, not indicating a generalised application of auctions (Held, 2010). Transaction-cost economics paints a similarly ambiguous picture about the universal suitability of RES auctions as governance instruments (Finon \& Perez, 2007; Kitzing, Mitchell, \& Morthorst, 2012). Nevertheless, the European Commission's 2014 guidelines for state-aid amount 
to an immediate, mandatory, and EU-wide application of auctions to the support of large-scale renewable electricity projects, to the initial alarm of many stakeholders (European Commission, 2013).

This article is primarily inspired by our observation that the RES auction was rehabilitated within mainstream European policymaking remarkably quickly. The generally accepted explanation of its rapid uptake rests on the auction's supposed ability to simultaneously enable static efficiency (i.e., improve cost-effectiveness) and increase market integration, while controlling the volume of deployment and total support payments (IRENA, 2017). With a few notable recent cases of faster-thananticipated deployment of renewables and associated support costs under feed-in systems (Inderberg, Tews, \& Turner, 2018; Mir-Artigues, Cerdá, \& del Río, 2018) and continuing reductions in contract prices achieved at auction (Mora et al., 2017), this explanation is prima facie credible. However, this accepted 'functionalist' explanation of the rise of renewable electricity auctions, we argue, cannot fully account for the auction's rapid ascent to becoming the main RES instrument in the EU.

RES support instruments encompass a huge range of diversity and the objectives set for the instrument (explicit or implicit) also vary widely between locations and over time, going far beyond the basic "cost efficiency" rationale (del Río \& Linares, 2014; Winkler, Magosch, \& Ragwitz, 2018). Often, the fundamental renewable energy policy goals remain to (continue to) deploy renewable electricity within a wider transformation towards a low-carbon economy. We hold that the EU-wide introduction of the auction is a significant, complex and somewhat surprising change to goal realisation, thereby requiring better explanation. Given the propensity for EU climate and energy governance choices to shape policy elsewhere (and vice-versa) through mechanisms such as international policy diffusion or transfer, the rise of the EU RES auction has global significance (Inderberg, Bailey, \& Harmer, 2017; Meckling, 2011). This article contributes to a clearer understanding of the mechanisms involved in such propagation.

The inspiration for this documentary study arises from two of the authors' participation as researchers in the AURES project, funded under the European Commission's Horizon 2020 programme to develop and disseminate expertise in RES auction design between January 2014 and December 2017. The authors were simultaneously working to create knowledge useful to policy practitioners seeking to solve problems related to the design of RES auctions and subsequently reflecting on that experience to pose more general questions such as that addressed in this paper. In this regard, the study draws on a research strategy loosely aligned with a tradition of participatory action research in public policy and organisations (Heatwole, Keller, \& Wamsley, 1976; Whyte, 1991).

Participation in the project did not result in direct or indirect observation of other project participants as research subjects (Johnson \& Reynolds, 2012). It did, however, trigger and inform the subsequent documentary analysis which provides the empirical data on which this study is based. All elements of the account are supported by (we hope compelling) documentary evidence, although we acknowledge that the experience of the authors inevitably brings a certain degree of interpretation in the selection and presentation of data. We have made every effort, however, to ensure that the account is "clear enough to be proven wrong" (Sabatier, 2007, p. 5) and invite other authors to do exactly that.

The remainder of this article is structured as follows: section 2 describes our analytical framework, distinguishing between demand for and supply of knowledge about governance instruments; section 3 deploys the framework to present an account of the rise of the RES auction in the EU; section 4 discusses the implications of the account and concludes.

\section{Conceptualising Demand for And Supply of New Governance Instruments}

As set out in the introduction, this paper starts from the assertion that a purely functional explanation of the ascent of the RES auction cannot account for the rapidity or scope of the policy change observed. In search of a more satisfactory explanation, this section develops an analytical framework that considers firstly the 'demand' for instrument change, which may take the form of exogenous economic or political developments. We briefly discuss some of the constraints on instrument selection that limit responsiveness to demand. Secondly we draw on recent work highlighting the significance of instrument 'supply'. That is, the networks of knowledge and expertise required to firstly select and secondly implement changes to instruments.

In the first instance, we reject the idea that governance instruments, the means by which "governments shape behaviour in pursuit of its policies" (Hood \& Margetts, 2007, p. xiii), are neutral tools that policymakers may simply pick up and 'use' to solve particular policy problems. Lascoumes and Le Gales $(2007$, p. 2) state that public policy instrument choice is often considered part of a "rationality of methods" with no inherent meaning. This rational "functionalist orientation" is attractive since it assumes that rationality is, or normatively should be, the basis of instrument choice (for example, Hepburn, 2006). But instrument choice is not a straightforward à la carte selection. Instead, it is greatly influenced by, and has influence on, contextual, historical and sociological factors. Instruments themselves firstly represent a condensed and particular form of knowledge about how to govern social processes and, secondly, induce specific effects outside the objectives set for them that "structure public policy according to their own logic" (Lascoumes \& Le Gales, 2007, p. 3; Simons \& Voß, 2017b).

Literature addressing the choice of policy instrument reflects two broad branches. The first helps to understand the demand for types of instrument in particular 
contexts and particular times while the second addresses the supply of instruments available to meet that demand. We anticipate that supply and demand processes are dynamic and interactive, with changes on the supplyside influencing demand for an instrument as well as vice-versa.

\subsection{Demand for New Instruments}

In addition to the practical, administrative constraints that influence instrument choice (can it and will it achieve its material aims?), the multi-level, nested nature of policy goals and actions sharply constrains the types of instrument that may be implemented in a particular context (Howlett, 2009). The ultimate choice of policy target and the tools used to reach them reflect not simply the aims of the policy area, but also wider policymaking and political contexts. New instrument adoption is not simply putting a 'new nib on an old pen'. As tools of governance, instruments must be coherent with the current "governance mode" or fairly stable sets of "favoured ideas and instruments" as well as with the objectives and preferences of the intermediate level "policy regime" in which public policy choices are determined (Howlett, 2009, p. 76). Consequently, change within these higher levels of abstraction, such as the fundamental governance arrangements of the economy or the broad policy objectives or logics, may create demand for change at the instrument level. This demand for new or updated instruments may not directly reflect the immediate goals, preferences and norms or "on-theground micro-requirement" of the policy targets that require specific tool calibrations (Howlett, 2009, p. 75).

Considering instrument choice as a governance process that takes place across multiple levels of abstraction highlights particular challenges for instrument choice in the EU. If we consider that EU governance takes the form of a multi-level "system of continuous negotiation" among various interdependent territorial levels, achieving coherence between levels, between policies and instruments becomes more complex again (Hooghe \& Marks, 2001; Marks, 1993, p. 392). Changes in the policymaking regime or governance mode at the European level may conflict with those at the national level, potentially (but not necessarily) further constraining national instrument choices (Jordan, Wurzel, Zito, \& Bruckner, 2003).

\subsection{Supply of New Instruments}

Recent theoretical developments have brought the supply-side of policy change into sharper focus. The notion that the policy subsystem is structured into identifiable actor groups engaged in complex interactions, collaborating and competing to define problems while searching for and legitimising solutions has a long heritage (Haas, 1992; Kingdon, 2010; Sabatier \& JenkinsSmith, 1993). More recent policy analysis is showing the importance of specialist 'instrument constituencies' in creating and sustaining a 'supply-push' for particular instrumental forms of governance (Simons \& Voß, 2017b).

Instrument constituencies help to understand how particular models of governance 'take on a life of their own'. As a particular governance instrument develops, knowledge of its functional particularities grows, attendant business opportunities emerge and political agendas are shaped such that a constituency of specialist actors "come to live through and for the development of a specific governance instrument" (Simons \& Voß, 2017b, p. 2). It is posited that instruments take on a 'social life' within the instrument constituency, lived through practices such as: "scientific theory building, data production and publishing, political issue framing, agenda setting, coalition building, business development, marketing and lobbying, management of innovation networks, professional organisation" (Voß \& Simons, 2014, p. 737).

Among propositions made in the nascent literature on instrument communities is an expectation that they are fundamentally future-facing structures in which actors "align their agency towards the development, retention, and expansion of the instrument" (Simons \& Voß, 2017 b, p. 6). Members of the instrument constituency may work simultaneously on specific implementations and the generic, conceptual articulation and refinement of the instrument to encourage its take-up and implementation elsewhere. The instrument constituency is central to a cycle of mutual reinforcement between implementation and an ever-more refined conceptual understanding of the instrument held in the model used to support further implementations (Simons \& Voß, 2017b; Voß \& Simons, 2014).

While the instrument constituency concept remains relatively new, there are early indications of its usefulness in explaining instrument choices in multiple policy fields (see Simons \& Voß, 2017a). Of particular relevance to this article are the insights afforded by the instrument constituency into the expansionary 'innovation journey' of EU climate and energy policy instruments such as the EU Emissions Trading System (Voß, 2007; Voß \& Simons, 2014). The implication here is that not only will the supply of specialist knowledge grow in response to demand, but that the level of demand will, in turn, be influenced by growing supply.

\section{A Brief History of a Policy Boom}

Following the generally unsatisfactory performance of auctions to realise new projects in Ireland, the UK and France in the 1990s, a decade-long hiatus occurred in their use for allocating RES support (Agnolucci, 2007; del Río \& Linares, 2014; Mitchell, 1995). In the last decade, however, a new wave of RES auctions began, largely focussed on developing nations (Azuela et al., 2014; IRENA, 2017; Winkler et al., 2018). In countries such as Brazil, South Africa, China and India, policymakers faced with surging demand for new electricity capacity began to hold periodic tenders in which renewable electricity 
projects could receive power purchase agreement (PPA) contracts (Baker, Newell, \& Phillips, 2014; IRENA, 2013).

The use of RES auctions in developing nations is based in the logic of state procurement (Lucas, del Río, \& Youba Sokona, 2017). State procurement of renewable capacity leads to auction usage for two reasons. Firstly, the use of auctions in other areas of electricity policy has been a widespread procurement tool, often for outsourcing electricity production by public distribution companies to private producers. The extension into RES procurement was uncontroversial (Maurer \& Barroso, 2011). Secondly, RES auctions, as 'competitive' instruments, are highly compatible with multilateral organisations' strict guidelines for procurement supported with donor capital (Ravallion, 2016), itself an artefact of the neoliberal preferences of many global institutions (Newell \& Phillips, 2016; Ockwell et al., 2017). This complementarity means that auctions are a common requirement for developing nations in implementing renewable electricity procurement programmes reliant on this support (Eberhard \& Naude, 2016).

African and South American countries, including Zambia, Ethiopia, Argentina and Uganda, utilise RES auction policies, often supported by multilateral finance. These cases are held by policymakers, academics and others as examples of successful RES auctions and used to recommend greater application of auctions for energy policy (Eberhard \& Naude, 2016; International Finance Corporation [IFC], 2017; Lucas et al., 2017; Maurer \& Barroso, 2011). These early experiences of RES procurement through auctions, although far from universally positive (Azuela et al., 2014), led to the enumeration of RES auction 'best practices'. Multilateral developmental organisations, such as the World Bank (WB) and IFC, began formalising and deploying these lessons in many countries (Maurer \& Barroso, 2011).

Alongside the collation and dissemination of RES auction knowledge by development organisations themselves, key players in the energy scene such as the IEA and IRENA began to build competence in auction design and implementation (IRENA, 2013). They were supported by a network of consultancies and research institutes in Europe, mainly in Germany and Denmark. This group is well regarded for its track record of expertise in analysing and designing renewable electricity policy support instruments on behalf of international donor organisations plus national and European policymakers through programmes such as Horizon 2020 (de Jager \& Rathmann, 2008; GTZ, 2009; Ragwitz et al., 2007). By 2013, international RES auction experience was being distilled into firm advice for policy as this expert group found new clients in the development sector willing to fund reports for recipient countries, such as South Africa (Ecofys, 2013).

Before 2014, very few EU member states had experimented with RES auctions (del Río \& Linares, 2014). Experience of auctioning support for multiple, privately developed projects, in the UK, Ireland and France, was characterised by poor project completion (del Río \& Linares,
2014). However, the combination of administratively set FIT and falling equipment pricing led to surging growth in installation, escalating policy costs, the over-rewarding of producers and associated budgetary challenges. Consequently, RES support in feed-in tariff countries such as Germany and Spain became politically salient (Geels, Sovacool, Schwanen, \& Sorrell, 2017; Mir-Artigues, Cerdá, \& del Río, 2015). Nevertheless, by 2014 few EU member states (the UK being a notable exception, see Fitch-Roy \& Woodman, 2016) had identified RES auctions as a viable candidate for primary large-scale RES instrument.

In 2014, the European Commission published revised guidelines against for evaluating RES instrument compliance with state-aid rules. The energy and environmental aid guidelines (EEAG), the Commission's official interpretation of the prohibition of state-aid under article 107(1) of the TFEU, require that, from 2017, member states offering support to renewable generators (except micro projects or novel technologies), are required to use "instruments, such as auctioning or competitive bidding process[es]". The reasoning for the blanket requirement is the prediction of lower costs and internal market compatibility (European Commission, 2014). Although EEAG is not the only factor creating demand for new auctions schemes in Europe (Leiren \& Reimer, 2018), it was a significant driver of auction adoption.

Adoption of the EEAG reflects broader trends in EU state aid law. Since 2001, Commission guidelines have acknowledged concerns about balancing environmental protection and compatibility of member state policy towards renewable energy with the single market. In 2001, a dispute involving the utility company, Preussen Elektra, over the legality of German FIT under EU competition law, was resolved by the ECJ, the court finding that, since revenues were not drawn from state resources, FIT did not constitute state aid (Kuhn, 2001). This legal precedent contributed to rapid growth in the use of the FIT across Europe. From a RES perspective, state-aid rules and renewable energy policy have since been kept broadly separate, despite ongoing monitoring and assessment of national renewable aid scheme compliance.

However, since 2005 a 'quiet revolution' in EU stateaid law has seen the expanded application of economic, rather than purely legal, principles for determining the Commission's interpretation of the Treaty's state-aid prohibition (Hancher, 2005, p. 431). This process of expansion towards the use of state-aid law in pursuit of broader public policy goals has been guided by a programme of State Aid Modernisation (SAM; Verouden, 2015). Here, the EEAG marks a clear shift towards state aid as "a regulatory and policy making tool rather than a mere monitoring and law enforcement tool" (Jansen, 2016, p. 597; Koenig, 2014). Not only are the legal principles of state aid compliance for RES support laid out, but the economic rationale and policy design in the form of auctions is also specified (Salerno, Douguet, \& Rious, 2018).

This expansion of the Commission's interpretation of EU Treaty article 107 to include policy objectives other 
than strict legal compliance has significantly strengthened European Commission competence. It also reflects a distinct internal shift of power over RES policy within the European Commission from the Energy Directorate General (DG Energy, formerly DG TREN) to DG Competition, something that had been sought for some time. For example, attempts by DG Competition in 2008 to ensure that DG TREN's proposals for the Renewable Energy Directive included an EU-wide tradable quota scheme resulted in a well-documented failure (Jacobsson et al., 2009; Nilsson, Nilsson, \& Ericsson, 2009).

Following the EEAG in 2014, RES auction design and implementation swept across Europe, with 13 Member States implementing RES auctions by 2018 and a further five with firm plans in place (Council of European Energy Regulators [CEER], 2018), creating strong demand for analysis and practical advice, largely met by the RES community of support specialists and supranational organisations such as CEER. To assist national governments, advocacy organisations with an EU climate and energy policy remit commissioned reports detailing key challenges of using RES auctions in Europe (Agora Energiewende, 2014). The European Commission concurrently engaged a consortium of RES support experts through its Horizon 2020 programme to undertake a three-year knowledge creation and dissemination project to increase understanding of RES auctions and contribute to the EU policy process (Kitzing et al., 2016; Mora et al., 2017).

Despite some high-profile successes, EU experience does not show a universal trend of auctions outperforming other financial support mechanisms to renewable electricity generators (Winkler et al., 2018). Indeed, there have been some notable failures of auctions to fulfil objectives formerly met with FIT (del Río, 2017). In particular, preventing participants from bidding at prices below the cost of realisation (and therefore not delivering), and fostering technology, participant and geographical diversity have all proved challenging. In addition, pursuing multiple policy goals, beyond lowest cost contracts, has presented challenges. Less mature technologies and smaller, community-based participants have proved especially difficult to target (Stratmann, 2017). Price reductions achieved with auctions are neither universal nor necessarily persistent, often resulting in slowing RES deployment (Huebler, Radov, \& Wieshammer, 2017; Winkler et al., 2018). It is, however, 'early days' and administrators' understanding of auction effectiveness is building. Widespread application of the instrument is credited with reducing technology prices and expanding renewable electricity installations (IRENA, 2017). The expertise for such learning is provided by researchers integrated with the network of specialists identified above as being involved in consolidating knowledge from developing countries as well as renewable energy support instruments more generally.

With the RES auction established in Europe, new international horizons are emerging. The auctioning idea, refined in Germany and other member states after the
EEAG, is being widely promoted across various international fora and between EU members, such as France and Germany (Ragwitz \& Anatolitis, 2017). In hosting the 2017 G20 summit, for example, Germany convened a series of climate and energy-focussed activities supported with analysis from actors such as IRENA and the IEA as well as the network of research and consultancy organisations (Ecofys, 2016). The resultant communiqué presents auctions as an uncontroversial instrument choice, stating that:

[Renewable energy] policy instruments have evolved and in some cases consolidated around standard models. An example is the evolution of renewable electricity support schemes in a number of countries from portfolio standards and feed-in-tariffs to auctions. (IEA \& IRENA, 2017, p. 32)

New regions such as South East Asia have been identified as ripe for the auction treatment, with the same cohort advising donor organisations such as USAID and policymakers in Asia (Ecofys, 2017; Tongsopit et al., 2017). Auctions are also promoted across the EU's Energy Community neighbourhood (Wigand \& Amazo, 2017).

\section{Discussion and Conclusions}

This article aimed to explain how RES auctions became central to EU renewable energy governance so rapidly. The narrative shows four key stages in RES auctions innovation. First, auctions were used as a procurement tool in developing countries where donor organisations and development banks were central to establishing a supply of expertise in how to use auctions to allocate RES contracts. Second, RES auctions fulfil DG Competition's preference for a competitive, potentially pan-European support policy. The rise of state-aid policy as the main driver of EU RES policy marks a distinct shift in governance mode, a crucial factor in creating demand for new instruments (Howlett, 2009). EU state-aid modernisation, combined with examples of budgetary difficulties with FIT, allowed DG Competition to not only enforce state-aid compliance but to effectively mandate the type of instrument member states could use. Thirdly, the 2014 EEAG created a laboratory of member state cases for fine-tuning RES auctions. Implementation has provided important data about how best to overcome challenges, enhancing the supply of auctions expertise held by a growing instrument constituency. Finally, the lessons learned first in developing countries, and in Europe, are being reflected in new regions, setting up an additional wave of international propagation.

A community of auction experts has accompanied the RES auction on its journey. Academic institutions and consultancies have helped develop, collate, interpret and conceptualise RES auctions. Much of the intellectual effort builds on collaboration established in earlier research programmes. But, whether this community 
constitutes the hypothesised 'instrument constituency' depends on whether its activities have been expansionary in that actors have sought, consciously or otherwise, greater implementation of RES auctions as an end rather that a means to an end. We argue that this has occurred. Consultants with demonstrable design expertise gained in developing countries found their skills in high demand across Europe due to the EEAG. The European Commission, by funding further research by the same group bought legitimacy that 'it could be done' while honing the instrument for further expansion. International organisations such as IRENA and national governments, once auctions were the 'only game in town', fed this process by procuring further analysis. We do not assert that these actors actively sought to promote auctions at the expense of alternatives. Between 2007 and 2014, renewable energy policy costs were salient in Europe, and talk of auctions was 'in the air'. We also acknowledge that some contemporary research in transitions and economics suggests that quantity-control instruments such as auctions may become more prevalent as renewable energy markets mature (Kitzing, Fitch-Roy, Islam, \& Mitchell, 2019).

However, we argue above that demand-side economic and political factors do not fully explain the rapidity with which the RES auction has displaced earlier instruments, often leading to diminished performance against goals (Winkler et al., 2018). While it is clear that there was demand for change, our account strongly suggests that those demand signals were amplified through mutual reinforcement between policymakers and analysts making the most of the competitive advantage afforded by their auctions expertise. Positive feedback between auction experts seeking new markets and new onthe-ground problem-solving experience enhanced this expertise, accelerating refinement and innovation in auction conceptualisation and design.

The spread of auctions suggests a degree of international convergence in RES governance, either through diffusion or by policy transfer (Dolowitz \& Marsh, 1996). The agency implied here in propagating RES auctions firstly between developing nations and the EU and secondly outwards to Europe's near neighbours suggests that the instrument constituency contributes to policy transfer, rather than policy diffusion, a more structural phenomenon (Marsh \& Sharman, 2009).

The observed trajectory of RES auctions described shows a distinct parallel to Vo $\beta$ and Simons' (2014) account of the Emission Trading System instrument constituency in which the EU was a key staging post in the governance innovation journey. The lessons learned through the EUDETS continue to inform the design of trading systems around the world (Inderberg et al., 2017). In much the same way, RES auctions were of peripheral interest until the scale of innovation and demand for instrument knowledge that can occur in an EU-wide implementation was realised. Viewing instrument choices through the lens proposed here may offer insights for analysts and policymakers. That instrument choice is initially shaped by changes to governance principles resulting from developments outside the policy area and thereafter by positive feedback within an instrument constituency provides policymakers with important knowledge. While demand-side pressures such as the growing tendency to use state-aid as a policy tool is ongoing and inevitable, the active role of policymakers on the supplyside of instrument innovation demands greater reflection. As Vo $\beta$ and Simons' (2014) acknowledge, the selffulfilling nature of instrument innovation reinforces the need for scrutiny of instrument choice, recognising that not all policy innovations are created equal. Apparent consensus around an instrument may reflect the state of supply of specialist instrument knowledge as well as the instrument's functional properties.

Finally, the importance and relevance of the concept of the instrument constituency may vary between policy areas and between different policymaking contexts. The degree of EU competence and therefore Europewide policy research coordination may be a critical factor. A comparative research agenda can help clarify these issues. Also, while there is growing recognition of how instrument constituencies complement theories of policy making such as the multiple streams approach (Fitch-Roy, Benson, \& Mitchell, 2018; Mukherjee \& Howlett, 2015) and advocacy coalition framework (Weible, 2017), similar engagement with new institutionalist research, discursive institutionalism in particular (Fitch-Roy, Fairbrass and Benson, 2019), could offer benefits to both fields.

\section{Acknowledgments}

The authors are grateful to three anonymous reviewers for their considered and helpful comments on an earlier version of this paper. This research was supported by the UK Engineering and Physical Sciences Research Council (EPSRC) [1402887] and the AURES and AURES II projects funded by the European Commission's Horizon 2020 programme [646172] and [817619].

\section{Conflict of Interests}

The authors declare no conflict of interests.

\section{References}

Agnolucci, P. (2007). The importance and the policy impacts of post-contractual opportunism and competition in the English and Welsh non-fossil fuel obligation. Energy Policy, 35(1), 475-486. https://doi.org/10.1016/j.enpol.2005.11.034

Agora Energiewende. (2014). Auctions for renewable energy in the European Union: Questions requiring further clarification. Retrieved from https://www.agoraenergiewende.de/fileadmin/downloads/publikatio nen/Hintergrund/Ausschreibungsmodelle/Agora_Auc tions-Paper_056_web.pdf 
Azuela, G. E., Barroso, L., Khanna, A., Wang, X., Wu, Y., \& Cunha, G. (2014). Performance of renewable energy auctions (Policy Research Working Papers No. 7062). Washington, DC: World Bank.

Baker, L., Newell, P., \& Phillips, J. (2014). The political economy of energy transitions: The case of South Africa. New Political Economy, 19(6), 791-818. https://doi.org/10.1080/13563467.2013.849674

Béland, D., Howlett, M., \& Mukherjee, I. (2017). Instrument constituencies and public policymaking: An introduction. Policy and Society, 37(1), 1-13. https://doi.org/10.1080/14494035.2017.1375249

Binmore, K., \& Klemperer, P. (2002). The biggest auction ever: The sale of the British $3 \mathrm{G}$ telecom licences. Economic Journal, 112, 74-96. https://doi.org/10.1111/1468-0297.00020

Butler, L., \& Neuhoff, K. (2008). Comparison of feedin tariff, quota and auction mechanisms to support wind power development. Renewable Energy, 33(8), 1854-1867. https://doi.org/10.1016/j.renene.2007.10.008

Council of European Energy Regulators. (2018). Tendering procedures for RES in Europe: State of play and first lessons learnt CEER Public Document. Brussels: CEER.

De Jager, D., \& Rathmann, M. (2008). Policy instrument design to reduce financing costs in renewable energy technology projects. Retrieved from http://iearetd.org/wp-content/uploads/2011/10/Policy_MainReport.pdf

Del Río, P. (2017). Designing auctions for renewable electricity support. Best practices from around the world. Energy for Sustainable Development, 41, 1-13. https://doi.org/10.1016/j.esd.2017.05.006

Del Río, P., \& Cerdá, E. (2014). The policy implications of the different interpretations of the cost-effectiveness of renewable electricity support. Energy Policy, 64, 364-372.

https://doi.org/10.1016/j.enpol.2013.08.096

Del Río, P., \& Gual, M. (2004). The promotion of green electricity in Europe: Present and future. European Environment, 14(4), 219-234. https://doi.org/10.1002/eet.357

Del Río, P., \& Linares, P. (2014). Back to the future? Rethinking auctions for renewable electricity support. Renewable and Sustainable Energy Reviews, 35, 42-56. https://doi.org/10.1016/j.rser.2014.03.039

Dolowitz, D., \& Marsh, D. (1996). Who learns what from whom: A review of the policy transfer literature. Political Studies, 21, 343-351. https://doi.org/ 10.1111/j.1467-9248.1996.tb00334.x

Eberhard, A., \& Naude, R. (2016). The South African renewable energy independent power producer procurement programme: A review and lessons learned. Journal of Energy in Southern Africa, 27(4), 1. https:// doi.org/10.17159/2413-3051/2016/v27i4a1483

Ecofys. (2013). Lessons for the tendering system for renewable electricity in South Africa from international experience in Brazil, Morocco and Peru. Retrieved from https://www.ecofys.com/files/files/ecofys-giz2013-international-experience-res-tendering.pdf

Ecofys. (2016). German G20 presidency: Ecofys supports German Ministry for Economic Affairs in the energy sustainability working group. Retrieved from https://www.ecofys.com/en/news/g20-presidencyecofys-supports-bmwi-in-prep-of-energy-workinggroup

Ecofys. (2017). Designing renewable energy incentives and auctions: Lessons for ASEAN. Retrieved from https://www.ecofys.com/en/publications/designingrenewable-energy-incentives-and-auctions-lessonsfor-asea

European Commission. (2013). Consultation: Draft guidelines on environmental and energy state aid (2014-2020). Retrieved from http://ec.europa.eu/ competition/consultations/2013_state_aid_environ ment/index_en.html

European Commission. (2014). Guidelines on state aid for environmental protection and energy 2014-2020. Official Journal of the European Union. Brussels: European Commission.

Finon, D., \& Perez, Y. (2007). The social efficiency of instruments of promotion of renewable energies: A transaction-cost perspective. Ecological Economics, 62(1), 77-92.

https://doi.org/10.1016/j.ecolecon.2006.05.011

Fitch-Roy, O. (2016). An offshore wind union? Diversity and convergence in European offshore wind governance. Climate Policy, 16(5), 586-605. https://doi.org/10.1080/14693062.2015.1117958

Fitch-Roy, O., Benson, D., \& Mitchell, C. (2018). Wipeout? Entrepreneurship, policy interaction and the EU's 2030 renewable energy target. Journal of European Integration. https://doi.org/10.1080/07036337.2018.1487961

Fitch-Roy, O., Fairbrass, J., \& Benson, D. (2019). Ideas, coalitions and compromise: Reinterpreting EU-ETS lobbying through discursive institutionalism. Journal of European Public Policy. http://doi.org/10.1080/13501763.2019.1567573

Fitch-Roy, O., \& Woodman, B. (2016). Auctions for renewable energy support in the United Kingdom: Instruments and lessons learnt. Penryn: AURES.

Geels, F., Sovacool, B. K., Schwanen, T., \& Sorrell, S. (2017). The socio-technical dynamics of low-carbon transitions. Joule, 1(3), 463-479. https://doi.org/10.1016/J.JOULE.2017.09.018

Gephart, M., Klessmann, C., \& Wigand, F. (2017). Renewable energy auctions-When are they (cost-) effective? Energy \& Environment. https://doi.org/10.1177/0958305X16688811

GTZ. (2009). Energy-policy framework conditions for electricity markets and renewable energies: 16 Country Analyses. Retrieved from https://www.ecofys.com/ files/files/gtz2009-en-terna-analysis-complete.pdf

Haas, P. M. (1992). Epistemic communities and inter- 
national policy coordination. International Organization, 46(1), 1-35.

Hancher, L. (2005). Towards an economic analysis of state aids. European State Aid Law Quarterly, 4(3), 425-431.

Heatwole, C. G., Keller, L. F., \& Wamsley, G. L. (1976). Action research and public policy analysis: Sharpening the political perspectives of public policy research. The Western Political Quarterly, 29(4), 597-609. https://doi.org/10.2307/448141

Held, A. (2010). Modelling the future development of renewable energy technologies in the European electricity sector using agent-based simulation. Karlsruhe: Fraunhofer Verlag.

Hepburn, C. (2006). Regulation by prices, quantities, or both: A review of instrument choice. Oxford Review of Economic Policy, 22(2), 226-247. https://doi.org/10.1093/oxrep/grj014

Hood, C., \& Margetts, H. (2007). The tools of government in the digital age. Palgrave Macmillan.

Hooghe, L., \& Marks, G. (2001). Multi-level governance and European integration. Lanham: Rowman \& Littlefield.

Howlett, M. (2009). Governance modes, policy regimes and operational plans: A multi-level nested model of policy instrument choice and policy design. Policy Sciences, 42(1), 73-89.

https://doi.org/10.1007/s11077-009-9079-1

Huebler, D., Radov, D., \& Wieshammer, L. (2017). Method or madness: Insights from Germany's recordbreaking offshore wind auction and its implications for future auctions key points. Retrieved from http:// www.nera.com/content/dam/nera/publications/2017 /PUB_Offshore_EMI_A4_0417.pdf

International Energy Agency, \& International Renewable Energy Agency. (2017). Perspectives for the energy transition: Investment needs for a low-carbon energy system. Retrieved from http://www.irena. org/DocumentDownloads/Publications/Perspectives _for_the_Energy_Transition_2017.pdf

International Finance Corporation. (2017). Creating markets for climate business. Retrieved from http:// www.ifc.org/wps/wcm/connect/974eedcb-f3d9-480 6-b32e-73720e6f4ca7/IFC-Climate_Investment_Op portunity_Creating_Markets.pdf

Inderberg, T. H. J., Bailey, I., \& Harmer, N. (2017). Designing New Zealand's emissions trading scheme. Global Environmental Politics, 17(3), 31-50. https://doi.org/10.1162/GLEP_a_00414

Inderberg, T. H. J., Tews, K., \& Turner, B. (2018). Is there a prosumer pathway? Exploring household solar energy development in Germany, Norway, and the United Kingdom. Energy Research \& Social Science, 42, 258-269.

https://doi.org/10.1016/J.ERSS.2018.04.006

International Renewable Energy Agency. (2013). Renewable energy in developing countries. Retrieved from https://www.irena.org/documentdownloads/public ations/irena_renewable_energy_auctions_in_devel oping_countries.pdf

International Renewable Energy Agency. (2017). Renewable energy auctions: Analysing 2016. Abu Dhabi: IRENA.

Jacobsson, S., Bergek, A., Finon, D., Lauber, V., Mitchell, C., Toke, D., \& Verbruggen, A. (2009). EU renewable energy support policy: Faith or facts? Energy Policy, 37(6), 2143-2146.

https://doi.org/10.1016/j.enpol.2009.02.043

Jansen, P. (2016). The interplay between industrial policy and state aid: Natural combination or strange bedfellows? European State Aid Law Quarterly, 575-602.

Johnson, J. B., \& Reynolds, H. T. (2012). Political science research methods (7th ed). Los Angeles, London, New Delhi, Singapore and Washington, DC: SAGE.

Jordan, A., Wurzel, R., Zito, A. R., \& Bruckner, L. (2003). European governance and the transfer of "new" environmental policy instruments (NEPIs) in the European Union. Public Administration, 81(3), 555-574. https://doi.org/10.1111/1467-9299.00361

Kingdon, J. W. (2010). Agendas, alternatives, and public policies (2nd ed.). Harlow: Pearson.

Kitzing, L., Fitch-Roy, O., Islam, M., \& Mitchell, C. (2019). An evolving risk perspective for policy instrument choice in sustainability transitions. Environmental Innovation and Societal Transitions. https://doi.org/10.1016/j.eist.2018.12.002

Kitzing, L., Islam, M., Soysal, E. R., Held, A., Ragwitz, M., Winkler, J., . . . Woodman, B. (2016). Recommendations on the role of auctions in a new renewable energy directive. Retrieved from http://aures project.eu/sites/aures.eu/files/media/documents/ REDII_memo_final.pdf

Kitzing, L., Mitchell, C., \& Morthorst, P. E. (2012). Renewable energy policies in Europe: Converging or diverging? Energy Policy, 51, 192-201. https://doi.org/10.1016/j.enpol.2012.08.064

Klemperer, P. (2004). Auctions: Theory and practice. Princeton, NJ: Princeton University Press.

Koenig, C. (2014). Where is state aid heading to? European State Aid Law Quarterly, 4, 491-493.

Krishna, V. (2010). Auction theory (2nd Ed.). London: Academic Press/Elsevier.

Kuhn, T. (2001). Implications of the preussen elektra judgment of the European Court of Justice on the community rules on state aid and the free movement of goods. Legal Issues of Economic Integration, 28(3), 361-376.

Lascoumes, P., \& Le Gales, P. (2007). Understanding public policy through its instruments: From the nature of instruments to the sociology of public policy instrumentation. Governance, 20(1), 1-21. https://doi.org/10.1111/j.1468-0491.2007.00342.x

Leiren, M. D., \& Reimer, I. (2018). Historical institutionalist perspective on the shift from feed-in tariffs towards auctioning in German renewable energy policy. Energy Research \& Social Science. 
https://doi.org/10.1016/j.erss.2018.05.022

Lucas, H., del Río, P., \& Youba Sokona, M. (2017). Design and assessment of renewable electricity auctions in Sub-Saharan Africa. IDS Bulletin, 48(5), 1-6. https://doi.org/10.19088/1968-2017.164

Marks, G. (1993). Structural policy and multilevel governance in the European Community. In A. Cafruny \& G. Rosenthal (Eds.), The state of the European Community (pp. 391-409). Boulder, CO: Lynne Rienner Publishers.

Marsh, D., \& Sharman, J. C. (2009). Policy diffusion and policy transfer. Policy Studies, 30(3), 269-288. https://doi.org/10.1080/01442870902863851

Maurer, L., \& Barroso, L. (2011). Electricity auctions: An overview of efficient practices. Washington, DC: The International Bank for Reconstruction and Development/The World Bank. https://doi.org/10.1162/105864001316907973

Meckling, J. (2011). The globalization of carbon trading: Transnational business coalitions in climate politics. Global Environmental Politics, 11(2), 26-50. https://doi.org/10.1162/GLEP_a_00052

Mir-Artigues, P., Cerdá, E., \& del Río, P. (2015). Analyzing the impact of cost-containment mechanisms on the profitability of solar PV plants in Spain. Renewable and Sustainable Energy Reviews, 46, 166-177. https://doi.org/10.1016/J.RSER.2015.02.005

Mir-Artigues, P., Cerdá, E., \& del Río, P. (2018). Analysing the economic impact of the new renewable electricity support scheme on solar PV plants in Spain. Energy Policy, 114, 323-331. https://doi.org/10.1016/J.ENPOL.2017.11.048

Mitchell, C. (1995). The renewables NFFO. Energy Policy, 23(12), 1077-1091. https://doi.org/10.1016/0301-4215(95)00123-9

Mitchell, C., Bauknecht, D., \& Connor, P. M. (2006). Effectiveness through risk reduction: A comparison of the renewable obligation in England and Wales and the feed-in system in Germany. Energy Policy, 34(3), 297-305.

https://doi.org/10.1016/j.enpol.2004.08.004

Mora, D., Kitzing, L., Soysal, E. R., Steinhilber, S., del Río, P., Wigand, F., . . . Woodman, B. (2017). Auctions for renewable energy support-Taming the beast of competitive bidding final report of the AURES project (Report D9.2). Retrieved from http://aures project.eu/sites/aures.eu/files/media/documents/ aures-finalreport.pdf

Mukherjee, I., \& Howlett, M. (2015). Who is a stream? Epistemic communities, instrument constituencies and advocacy coalitions in public policy-making. Politics and Governance, 3(2), 65.

https://doi.org/10.17645/pag.v3i2.290

Newell, P., \& Phillips, J. (2016). Neoliberal energy transitions in the South: Kenyan experiences. Geoforum, 74, 39-48.

https://doi.org/10.1016/j.geoforum.2016.05.009

Nilsson, M., Nilsson, L. J., \& Ericsson, K. (2009). The rise and fall of GO trading in European renewable energy policy: The role of advocacy and policy framing. Energy Policy, 37(11), 4454-4462.

https://doi.org/10.1016/j.enpol.2009.05.065

Ockwell, D., Byrne, R., Urama, K., Ozor, N., Kirumba, E., Ely, A., ... Gollwitzer, L. (2017). Debunking free market myths: Transforming pro-poor, sustainable energy access for climate compatible development. In F. Nunan (Ed.), Making climate compatible development happen (pp. 130-150). Routledge.

Ragwitz, M., \& Anatolitis, V. (2017). Ausschreibungen im EEG 2017 (Les appels d'offres dans la loi allemande sur les energie renouvables) [Auctions in the German renwable energy act]. Retrieved from https:// energie-fr-de.eu/fr/manifestations/lecteur/salon-eworld-2017-side-event-sur-les-nouveaux-mecanismes -de-soutien-et-appels-doffres-en-france-et-en-allema gne.html?file=files/ofaenr/03-salons-interventions/ 2017/170208_E_world/02_Prof_Dr_Mario_Ragwitz

Ragwitz, M., Held, A., Resch, G., Faber, T., Haas, R., Huber, C., . . Heyder, B. (2007). OPTRES final report. Retrieved from https://ec.europa.eu/energy/ sites/ener/files/documents/2007_02_optres.pdf

Ravallion, M. (2016). The World Bank: Why it is still needed and why it still disappoints. Journal of Economic Perspectives, 30(1), 77-94. https://doi.org/10.1257/jep.30.1.77

Sabatier, P. A. (2007). Theories of the policy process (2nd ed.). Boulder, CO: Westview Press.

Sabatier, P. A., \& Jenkins-Smith, H. C. (1993). Policy change and learning: An advocacy coalition approach. Boulder, CO: Westview Press.

Salerno, F. M., Douguet, S., \& Rious, V. (2018). Compatibility of RES: A legal and economic approach. In L. Hancher, A. Hauteclocque, \& F. M. Salerno (Eds.), State aid and the energy sector (pp. 113-144). Haywards Heath: Hart Publishing.

Simons, A., \& Voß, J. (2017a). Policy instrument constituencies and their role in formulating and disseminating policies. In M. Howlett \& I. Mukherjee (Eds.), Handbook of policy formulation (pp. 355-372). Cheltenham: Edward Elgar.

Simons, A., \& Voß, J. (2017b). The concept of instrument constituencies: Accounting for dynamics and practices of knowing governance. Policy and Society, 37(1), 13-45. https://doi.org/10.1080/14494035.2017.1375248

Stratmann, K. (2017). Der Bürgerwind-Trick [The citizen wind trick]. Retrieved from http://www. handelsblatt.com/my/politik/deutschland/aenderun gen-im-erneuerbare-energien-gesetz-der-buergerwind -trick/20155746.html

Sturdy, A. (2017). Promoting solutions and coconstructing problems-Management consultancy and instrument constituencies. Policy and Society, 37(1), 74-89. https://doi.org/10.1080/14494035.2017.1375247

Szulecki, K. (2017). Poland's renewable energy policy mix: 
European influence and domestic soap opera. Oslo: Cicero. https://doi.org/10.2139/ssrn.2964866

Szulecki, K., Fischer, S., Gullberg, A. T., \& Sartor, O. (2016). Shaping the 'Energy Union': Between national positions and governance innovation in EU energy and climate policy. Climate Policy, 16(5), 548-567. https://doi.org/10.1080/14693062.2015.1135100

Thaler, R. H. (1988). Anomalies the winner's curse. The Journal of Economic Perspectives, 2(1), 191-202. https://doi.org/10.1002/9780470015902.a0022495

Toke, D. (2015). Renewable energy auctions and tenders: How good are they? International Journal of Sustainable Energy Planning and Management, 08, 43-56.

Tongsopit, S., Amatayakul, W., Saculsan, P. G., Nghia, V. H., Tirpornvitoon, C., Favre, R., . . Afanador, A. (2017). Designing renewable energy incentives and auctions: Lessons for ASEAN. Retrieved from http:// usaidcleanpowerasia.com/publications/reports/Renew ableEnergy-IncentivesReport-20170904-FINAL.pdf

Verouden, V. (2015). EU state aid control: The quest for effectiveness. European State Aid Law Quarterly, 4, 459-464.

Voß, J.-P. (2007). Innovation processes in governance: The development of "emissions trading" as a new policy instrument. Science and Public Policy, 34(5), 329-343.

https://doi.org/10.3152/030234207X228584

Voß, J.-P., \& Simons, A. (2014). Instrument constituen- cies and the supply side of policy innovation: The social life of emissions trading. Environmental Politics, 23(5), 735-754. https://doi.org/10.1080/09644016.2014.923625

Weible, C. M. (2017). Instrument constituencies and the advocacy coalition framework: An essay on the comparisons, opportunities, and intersections. Policy and Society. https://doi.org/10.1080/14494035.2018.1417705

Weitzman, M. L. (1974). Prices vs. quantities. The Review of Economic Studies, 41(4), 477-491.

Whyte, W. F. (1991). Participatory action research. London: Sage Publications.

Wigand, F., \& Amazo, A. (2017). RES auctions: Insights for the Energy Community from AURES. Retrieved from http://www.irena.org/-/media/Files/IRENA/Agency/ Events/2017/Mar/8/Ecofys-RES-auctions--Insightsfor-the-Energy-Community.pdf

Winkler, J., Magosch, M., \& Ragwitz, M. (2018). Effectiveness and efficiency of auctions for supporting renewable electricity-What can we learn from recent experiences? Renewable Energy, 119, 473-489. https://doi.org/10.1016/j.renene.2017.09.071

Woodman, B., \& Mitchell, C. (2011). Learning from experience? The development of the renewables obligation in England and Wales 2002-2010. Energy Policy, 39(7), 3914-3921.

https://doi.org/10.1016/j.enpol.2011.03.074

\section{About the Authors}
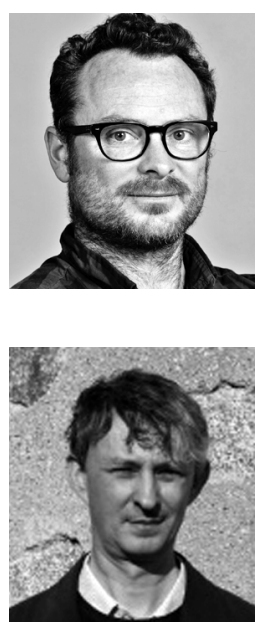

David Benson is an interdisciplinary environmental social scientist and faculty member of the Environment and Sustainability Institute (ESI) at the University of Exeter, a globally leading establishment for research into sustainable development. His interdisciplinary research, at the interface between environmental and political sciences, encompasses a range of subject areas including water, climate and energy governance.

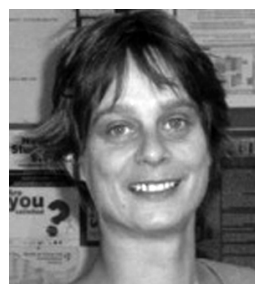

Bridget Woodman is Deputy Director of the Energy Policy Group at the University of Exeter. Her multidisciplinary research is focused on examining the design and implementation of policies and regulations, and their implications for a shift to more sustainable energy systems. 